\title{
Literature Review on Cultural Governance ANd Cities
}

\author{
Jordi Baltà Portolés \\ UNESCO - Universitat Oberta de Catalunya \\ Vesna Čopič \\ UNESCO - University of Ljubljana \\ Andrej Srakar \\ University of Ljubljana
}

\begin{abstract}
This article, written by Vesna Čopič, Andrej Srakar and Jordi Baltà, examines recent literature in the field of cultural governance, with particular emphasis on its implications for local cultural policies.
\end{abstract}

KeYWORDs: Cultural governance, cultural policy, cities, local governments, decentralisation, governance.

RESUM: Aquest article, escrit per Vesna Čopič, Andrej Srakar i Jordi Baltà, analitza la bibliografia recent en l'àmbit de la governança cultural, amb especial èmfasi sobre les seues conseqüències en les polítiques culturals locals.

Paraules Clau: governança cultural, política cultural, ciutats, administracions locals, descentralització, governança.

RESUMEN: Este artículo, escrito por Vesna Čopič, Andrej Srakar y Jordi Baltà, examina la bibliografía reciente en el ámbito de la gobernanza cultural, con especial atención a sus repercusiones en las políticas culturales locales.

Palabras clave: gobernanza cultural, política cultural, ciudades, administraciones locales, descentralización, gobernanza. 


\section{Introduction and Background}

I n late 2011, the European Commission's Directorate-General for Education and Culture (DG EAC) asked the European Expert Network on Culture (EENC) to prepare a literature review examining recent academic contributions to the concept of 'cultural governance'. The resulting document, written by Vesna Čopič and Andrej Srakar, was later used in the preparations for a conference entitled 'Cultural Governance in a Globalising World: Better Governance for the Cultural and Creative Sector', held in August 2012 under the Cypriot Presidency of the Eu. One of the papers and reports regularly produced by the EENC at the request of DG EAC in order to foster reflection on cultural policies, it was later published online. ${ }^{1}$

The aforementioned literature review analysed over 50 publications published between 2006 and 2011, examining the notion of cultural governance, its implications in cultural policy, relations with the creative sector, the governance of individual cultural institutions and a set of related issues, stressing the manifold uses and implications of the term. Building on that experience, a more specific analysis of cultural governance and its implications for cultural policy in cities has been prepared for this issue of Kult-ur. The article examines a selection of documents included in the previous literature review, with particular emphasis on those which help to further analyse the key terms and which have implications for cultural policy at a local level. In addition, some earlier or more recent references have been included, where they help to put reflections in context and connect them with other relevant contributions.

\section{Conceptualisation of the Notion of Cultural Governance}

Cultural governance is still a concept that defies precise definition and is not recognised as a distinguished research topic. If the term is defined as 'governance of culture' then, according to Čopič and Srakar $(2012,6)$ it is "composed of two sub-areas: (1) the new approaches to the formulation and

1. Čopič; V. and A. Srakar (2012): Cultural Governance: A Literature Review, EENC Paper, January 2012; available at $<\underline{\text { http://www.eenc.info/news/cultural-governance-lit- }}$ erature-review/>. 
implementation of sectorial cultural policy that are inspired by the interaction between the state, the civil society and the market; and (2) the improvements in the steering and supervision of cultural organisations that lead to efficiently-, expertly-, independently- and transparently-operating cultural organisations". If the conceptualisation of cultural governance takes into consideration the diverse meanings and the genealogy of the term 'culture' and the omnipresence of the term 'governance' in all development policies, then it requires a multidisciplinary approach to the syntax connecting a number of different theoretical areas, ranging from cultural studies to public administration, organisational theory, political science, economics and sociology. Ever since the 1990s the term 'governance' has navigated between the world of experts and academics, international organisations such as the World Bank and civil movements, all of them in search of alternative ways of arranging public affairs but not at all with the same notion in mind. Similarly the syntax 'cultural governance' calls for further clarification.

Thomas Schmitt deals with the concept of cultural governance from the perspective of sociologically-informed cultural studies (Schmitt, 2011). ${ }^{2}$ Schmitt steps beyond the epistemological boundary set by sociology, re-introducing hard-sociology into the field of cultural studies, more precisely by re-defining the concept of culture through Weber's age-old, a thousand-times-surpassed definition of culture (as production of sense and meaning); unsurprisingly, when this part comes to Adorno and Horkheimer's concept of cultural industry, the initial conceptualisation slowly loses its strength (ibid, 11-18). However it shows both the diversity of 'culture' terms and the decisive relationship of culture and society. Such broad significance of cultural phenomena leads to the question of transformation of cultural facts through social changes (including political, economic or technological influences) on the one hand and the question of influence of cultural phenomena on society as a whole and their functional sectors in particular, on the other. The initial concern with the concept of culture serves as a preliminary exploration of the concept of governance (ibid, 19-23): despite the author's open aversion to post-structuralism it seems that the concept of governance, distinguished

2. This is a working paper, which was written as a work-in-progress as part of the author's doctoral thesis. 
from government, functions as Foucault's concept of governmentality (1991), namely, the understanding of power as something that cannot be reduced to the pyramidal effect of official institutions and, quite the contrary, something that spreads throughout society and is dependent on everyone's involvement. Thus, when it finally comes to the concept at hand, namely, cultural governance, the main contribution is - apart from providing a résumé of existing theories of cultural governance - to forge a concept that allows us not only to see how power is shaping culture but, and most interestingly, how culture is shaping power. The specific concept of cultural governance is thus introduced as a research concept for the humanities and social sciences.

On the opposite side of the wide concept of cultural governance in the broader sense is a sectoral concept of cultural governance in a narrow sense, namely governance of culture understood as government cultural policy based on the relationship between culture and administration. Cultural governance could therefore be seen as a concept on the border of cultural policy and cultural management, therefore on the border of macro- and micro-oriented views. The latter also concerns the governance of cultural institutions which entails the direct and indirect involvement of government. Political interference through rules, structures and constitutions (in the sense of politics) and specific steering attempts (in the sense of policies) may endanger the anticipated autonomy of cultural institutions (aimed at protecting artistic integrity from political preferences). Incompatibilities could "lead to conflictive forms of cultural governance" (Schmitt, 2011: 49). From this point of view the impact of the introduction of a doctrine of new public management (NPM) on the governance of culture that is motivated by effectiveness and efficiency and results in a market logic in 'projectification' and shorter-term employment; new organisational forms, decentralisation, and fragmentation of control; frequent external audits etc., (Lindqvist, 2012) should be considered when discussing governance as a new democratic promise for the cultural sector, among others.

The considerations about cultural governance in the narrow sense could be elaborated much more broadly if we look at it from different viewpoints, as Raymond Weber does in his paper 'What governance for Culture and the Cultural Sector?'. He includes in his conceptualisation development cooper- 
ation and international relations; cultural rights; the knowledge society, the creative economy and ICT (information and communication technologies).

Even in the narrow sense cultural governance should be put in a broader political context referring to the burning issues of the modern world: legal-rational legitimacy monopolised by elected politicians in the post-national situation when states are no longer capable of coping with ever-growing social demands; the emergence of a civil vision of democracy based on the re-organisation of power (going beyond public consultation and deliberative democracy and denying parliamentarian democracy as an exclusive channel to policy decision-making); the shift from government to governance as "our joint and uneven terms of engagement with the complex field of economic, social, political and cultural power relations in which we are all 'stakeholders"' (Mercer, 2012), the processes such as privatisation, decentralisation, incorporation etc., which do not only mean fragmentation of the decision-making systems but also the withdrawal of the state from the public sector and the emergence of new problems (environment, security, exclusion, etc.) which do not fit into sectorial policies. This selection of issues (some of which are cited by Weber and some added) requires the interaction between state, market and civil society.

When answering the question "How does society construct its own capacities to intervene in the essential problems identified?", Weber also stresses the importance of social and cultural capital in a learning society and the need for an ethical and systemic approach for sustainable development.

There is one aspect missing from this set of issues which deserves special mention, namely the creative industries discourse, since it represents the potential shift of the cultural policy paradigm without pointing it out. When the main justification for public funding of culture becomes the discourse of profit we need to be aware of the consequential marginalisation of the non-use values of culture ${ }^{3}$ and other arguments that have so far been legitimising culture as a public good. In his last book, Dragan Klaić (2013) gave an in-depth clarification of the difference between public and commercial theatres, under-

3. According to Frey and Pommerehne (1989) non-use values are existence, option, bequest, prestige and educational values. 
lining the distinct virtues, values and benefits of public theatre. Blurring this distinction would deprive public theatre of its public mission and ultimately de-legitimise its claim to public support (ibid.: 3). The public character of culture, i.e., the public good rationale, is therefore another important viewpoint for the conceptualisation of cultural governance.

According to Weber another significant marker is hidden in the syntax of good governance through which in the 1990s the World Bank and some other international organisations started to stress the need for a new approach to the way in which public issues were governed. Within this syntax the term governance is highly judgemental, functioning as a benchmark with the application of certain standards (such as the rule of law, transparency, participatory development, democratisation, human rights, etc.).

When cultural policy becomes transversal and achieves coherence between actors and functions, then the cultural system participates through interactions with the 'production' of society. Speaking about strengthening culture as a public good, building capacities to foster better governance, managing cultural diversity and constructing of citizenship, promoting the participation of all stakeholders, reviving citizens' public spaces, fostering ethical challenges, involving public, economic and civil sectors in 'coproduction' and consolidating through the respect of human rights, elaborated further in Weber's text, serves for the conceptualisation of cultural governance and could lead to cultural governance as a set of standards aimed at a new 'cultural contract'.

\section{Current Trends in Cultural Governance}

Our overview of current trends in cultural governance will focus on four main aspects of cultural governance which open new directions in terms of research as well as policy issues: (1) value-based governance; (2) independence from government funding and arm's length institutions; (3) impact of the current financial crisis; and (4) governance codes.

Value-based governance is a trend that relates to the inclusion of a specific sort of thinking linked to public economics in management, policy and governance aspects of culture. John Holden $(2004 ; 2006)$ proposes that values can be 
classified as intrinsic, instrumental, and institutional. Instrumental values relate to culture being funded by governments primarily because of its economic and social benefits; intrinsic values relate to culture being funded as a public good in its own right; while institutional values are mainly related to management tools to improve the way in which cultural organisations serve their publics (Holden \& Baltà, 2012: 6). Holden and Baltà summarise the debate and literature in the field of the public value of culture in their 2012 paper ( $\mathrm{ibid}$.).

Perhaps a more concise (and certainly more widely accepted, at least in economic circles) terminology has been proposed by Frey and Pommerehne (1989) and Throsby (2001): use values, related to market dimensions of culture; non-use values (i.e., existence, option, bequest, prestige, educational values), related to market failure and justifications for public support to the arts; and cultural values (i.e., symbolic, spiritual, aesthetic, authenticity, social, historical values), related to values specific to the field of arts which cannot be expressed in money terms. The main essence of the argument has been summarised by Srakar and Čopič (2012 a): firstly, there is a danger in the inclusion of economic concepts that the predominant focus will be placed on instrumental (use) values, and that the more culture-specific (intrinsic/ non-use and cultural) values will be neglected; and secondly, whenever the existence of significant non-use values of a certain cultural good or event can be proved, a beneficial externalities argument (see e.g., Baumol, 2003) for public support to the arts applies (see e.g., Bille Hansen, 1997; Srakar, 2010; Srakar \& Čopič, 2012 b).

A sound policy and governance of culture would therefore take account of all different types of values and place a focus on non-use values (such as justification for public support to the arts) and cultural values (such as the most culture-specific values). Paraphrasing Bruce A. Seaman (1987), the current game that cultural policy makers play by resorting to instrumental values is a dangerous game, "choosing to play one of the weakest cards, while holding back their aces" (Seaman, 1987: 280). Recent documents (see Cultural Economy Network, December 2013) show that the focus of international cultural organisations is being drawn away from the market values/creative industries framework towards hopefully more 'culturally' related arguments for funding and governance in culture and the arts. 
The second trend is related to independence from government arts funding. Independence is one of 21 key strategic dilemmas in cultural policy identified in Matarasso and Landry's key publication Balancing Act: Twenty-one Strategic Dilemmas in Cultural Policy (Matarasso \& Landry, 1999). Madden's (Madden, 2009) report emphasised that the degree of independence depends on a number of factors: (1) the institutional structures through which policy is delivered; (2) the decision makers who determine resource allocation; (3) the policy instruments (or 'tools') used; and (4) the formal and informal rules, conventions and customs that influence behaviours of agents in the system.

Data in Madden's report suggests that a 'shorter arm' (limited freedom of action by agencies) approach to arts support may be more common internationally than a 'longer arm' approach. Cultural policy analysts have noted a growing 'mixed approach' to arts support around the world: the arm has grown shorter in countries that have had a 'long arm' and vice versa. In mixed arts support systems, it is critical that the elements of the arts policy system the agencies, instruments, personnel Čopič and rules - be applied where they are best suited (Madden, 2009: 27). In general there exists some evidence that systems with greater pronouncement on the arm's length principle in the arts are showing better performance in a number of economic and institutional indicators (see e.g., Toth, 2012). Still one can question the real influence of the arm's length principle as the resources provided to such agencies are usually limited to about $5-15 \%$ of the total national cultural budget.

Another important issue for cultural governance is the impact of the current financial crisis. In a recent paper, Čopič and colleagues claim that the crisis has had a mixed impact, being mostly visible at the level of state public funding and much less so at the level of local public funding (see Čopič et al., 2013). In an earlier paper, Bonet and Donato argue that the crisis could be a great opportunity for a structural change in the cultural sector, at both the policy and the organisational levels (Bonet \& Donato, 2011). They clearly point to challenges of the crisis for both governance and management of cultural institutions and claim that "the crisis could be overcome only through a radical change in the current governance and management models" (ibid.: 8). They furthermore claim that a change is called for "both at an institutional 
level (policy) and at an organizational level (management)" (ibid.: 9). They advocate a move from the micro-oriented perspective to a multi-scale approach based on cooperation networks. Finally, they outline some strategies for enhancing the governance and management models in the cultural sector, such as improving the decision-making process; stimulating organisations to cooperate with other subjects; addressing the on-going process of technological innovation using these innovations to develop new business models that could be shaped around market opportunities and challenges, as well as around people's expectations (ibid.: 9). Clearly, the problems of the financial crisis demand a revised perspective in the governance of cultural institutions, especially in the light of the issue of financing and interrelationships among institutions in the cultural sector.

In an important paper from 2009, Governance Now: the hidden challenge of leadership, several authors discuss the possibilities of better governance and propose the adoption of a governance code. The authors claim that good governance does not require changes to the current model, but rather it is a matter of effective leadership and vision. Some improvements are proposed such as introducing a form of compensation for trusteeship, which is currently a voluntary role, and developing a better understanding of the role among the general public, therefore improving recruitment processes. A key issue for good governance is also the relationship between the board chair and the chief executive. Further proposals in this area made by the authors of this document include providing better training before taking up an executive position and establishing a forum for networking and ongoing peer support. A code of governance for the cultural sector is then discussed in detail, which includes a toolkit for self-assessment on governance performance and suggestions about what new policies are needed. Other papers in the literature (e.g., cos, Stichting Kunst \& Zaken, 2008) also discuss the possibility of a cultural governance code as a mechanism to steer better governance in the cultural sector.

As cultural governance and governance itself is a relatively new concept the outcomes of its development are yet to be seen. Its position as an interdisciplinary concept on the border of macro and micro (as well as meso) analysis promises interesting developments in the future, while its evolution will of 
course mainly depend on whether it will be able to adequately respond to the challenges ahead.

\section{Decentralisation and Interterritorial Cooperation (and Competition)}

The general trends towards cultural governance depicted in the previous section are nowadays also influenced by shifts in geographical centralities and relations between regions and territories, which ultimately have an impact on policy and management processes.

A number of trends can be observed in this context, including (1) decentralisation, which Zan et al. (2007) have analysed with particular regard to heritage policies in Italy; (2) the increasing centrality of regions as spaces combining a political, economic, social and cultural dimension (Föhl, 2009); and (3) inter-territoriality, which involves cooperation among territorial authorities across national borders or within single states, as evidenced by the case of Euroregions (Perrin, 2010).

This increasingly complex map of stakeholders and governance spaces presents different degrees of formalisation and strength, with some (e.g., regions in largely decentralised or federal states) presenting a more solid nature than others (e.g., Euroregions, which, Perrin argues, still remain 'arenas' for negotiation, the effectiveness of which often depends on the political will of their constituent parts).

At the same time, new negotiation processes emerge in this context as regards the distribution of power among different tiers of government. In some cases, this may lead to the assumption of different but complementary roles, as in the 'balanced division of cultural labour' in France between large cities, which are mainly responsible for creative and innovative policies, and regions, which are responsible for policies concerning identity and heritage (Perrin, 2010, quoting Guy Saez). Likewise, in the uK (and particularly England) Stevenson et al. (2010) identify an increasing consensus among different tiers of government, which have adopted a policy discourse recognising the convergence of economic, social and cultural policies, the latter being expected to contribute to a wide range of public policy objectives. Yet as in the 
case of France, slightly different tones may be visible in specific policy documents: the focus on national prestige or identity that underpins central government initiatives is seldom present within regional planning units or local authorities, which in turn privilege the implications of culture for economic development and social cohesion and generally adopt more plural, inclusive and precise definitions of culture.

Alongside this confluence of discourses and complementary roles, shifts in the distribution of territorial power are often ingrained with tensions and complex policy decisions. This is confirmed by decentralisation processes in cases like Italy, which Zan et al. suggest should be analysed from a broader perspective than that generally used: "Centralisation and decentralisation are not necessarily mutually exclusive. Rather, what is called for is a less polarised dialogue between the two concepts, culturally and administratively speaking" (2007: 51). Rather than seeing it as a 'monolithic category', they propose that two dimensions of decentralisation (professional control and administrative responsibility) be distinguished - in cases such as heritage preservation and management in Italy, a certain degree of centralisation of professional control may be desirable, in order to ensure technical consistency and retain independence from local lobbying. This may be complemented with decentralisation of heritage ownership and management in certain cases.

The notion of 'desétatisation', involving a combination of increased managerial authority, outsourcing and decentralisation, emerges as one element which could reconcile the extreme views existing around discussions on the decentralisation of heritage policies: "Désetatisation can offer a solution - a multi-dimensional response in itself even - which still preserves the fundamentals of cultural heritage as 'public goods', without condemning superintendents and curators to be victims of the extreme rigours of public law in activities run as public entities. There has to be an acceptable compromise solution through relaxing a substantial number of the constraints imposed upon public bodies while still upholding the 'public good' ethos in cultural heritage..." (Zan et al., 2007: 66). The authors also stress, however, that specific national factors, such as recent political trends and the nature of cultural assets, may influence decisions, thus suggesting the need to design models adapted to each context. 
Shifts in governance are also visible within regions, where an increasing number of stakeholders - including public, private and non-profit actors are active in the definition of cultural strategies. Föhl (2009) describes the different degrees of cultural cooperation that can exist in regional spaces, as well as the factors which may influence its effectiveness. The traditional models of relations in the private sector (market-based) and the public sector (hierarchy-based) increasingly give way to new forms of collaboration and cooperation, which may include horizontal (among organisations providing similar services), vertical (among organisations providing compatible services, within the same sector) or lateral (among organisations in different sectors) cooperation, as well as combinations thereof.

Regional authorities may adopt collaboration not only as an objective of their activities but also as a planning method, which in the long term may lead to the emergence of shared visions in regional cultural development, as shown by the Land of Brandenburg's Kulturentwicklungskonzeption, which since 1997 has involved collaboration between regional and local authorities in planning and delivery processes. In this and other cases, a number of success factors can be identified: a small number of well-organised partners; homogeneity or compatibility of interests; and clear allocation of contributions and impacts. An underpinning reflection on cultural policy and cultural management, which allows for clear priority-setting and role distribution, also emerges as an essential aspect.

\section{Cultural Governance in Cities: Key Issues}

The changes in the territorial distribution of power and its implications for cultural governance depicted above have also been felt at the city level. Among the factors which help to explain this are (1) the impact of globalisation ("Today's cities are the spaces where globalisation becomes clearly and immediately obvious. Creative processes take place in local communities. New shared imaginaries are originated in local communities", Pascual, 2008: 15); (2) the need to develop economic and sustainable development strategies adapted to local circumstances (Sacco et al., 2009; Fleming et al., 2011); (3) the centrality of cities as spaces for the exercise of rights and democracy 
(Pascual, 2008); and (4) the ability of local authorities to react more rapidly to emerging needs (Saukkonen and Pyykkönen, 2008). As in the case of decentralisation processes observed in the previous section, tensions between national and local governments often arise, since the latter are seldom acknowledged as important agents in national governance, consulted in national legislation which affects them or provided with the necessary resources to implement it (Pascual, 2008).

As in other tiers of government, the increasing complexity of cultural governance in cities is partly the result of the observation of new areas of confluence between cultural activities, resources and policies, on the one hand, and other policy objectives, on the other. This is best exemplified by the integration of cultural aspects in the contemporary definitions of human and sustainable development, wherein, however, a variety of approaches is apparent. In some instances, the case for culture being understood as a specific, interconnected pillar of sustainable development alongside the economic, social and environmental dimensions is put forward: Pascual, quoting Jon Hawkes, suggests that the old triangle of sustainable development be superseded by a new square of sustainable development, including a cultural pillar and with governance as a space for negotiation and complementarity. This is grounded on the increasing importance of the so-called intrinsic values of culture' (see also Holden, 2004 and 2006) and provides reinforced legitimacy for cultural policies: "More than ever, contemporary phenomena require a personal analysis that can only be provided by access to, and practice with, cultural activities. [...] Cultural policies create the opportunities that no other public sphere provides. Cultural policies are built on the so-called intrinsic values of culture, which include concepts such as memory, creativity, critical knowledge, rituality, excellence, beauty, diversity" (Pascual, 2008: 12).

In other cases, the importance of culture and its legitimacy as an area of public policy is mainly sustained on the basis of its social and, particularly, economic externalities, as in the complex analysis of cultural districts presented by Sacco et al. (2009). In the transition from industry-based to postindustrial economies, cultural elements play a strategic role in territorial competition and in increasing the value of goods. A major aspect which distinguishes a traditional industry-based approach from a culture-based approach to eco- 
nomic development is the latter's focus on the horizontal integration of firms from different value chains. Several examples of cultural districts in Europe and North America, and the combination of resources and approaches in each of them, are examined. On this basis, 12 strategic lines of action underpinning local cultural development and its contribution to broader areas of local government are identified; among them is the quality of local governance.

Among the other areas of confluence which serve to stress the increasing centrality of culture for local policy objectives is cultural diversity. As Saukkonen and Pyykkönen (2008) observe in the case of Finland, cities experience increasing diversity first-hand and are better suited to conceive policies adapted to it; this is not solely the precinct of cultural policy, but increasingly an area which informs other policy fields.

Literature addressing local cultural governance often combines an analytical and an 'applied' approach, the latter leading to the description or suggestion of potential policy instruments. Given the confluence of policy objectives outlined above, it should come as no surprise that the need for 'joined-up' policymaking and transversal policy bodies is frequently pointed out. Saukkonen and Pyykkönen identify three main kinds of administrative and organisational arrangements which operate as points of contact between cultural policy and diversity within Helsinki's public policies: the integration of ethnic diversity in the standard work of cultural institutions (as previously done with diversity of age, gender, disability, etc.); the integration of the arts and culture as elements or resources in other public services provided to newcomers (e.g., education, healthcare, social policy); and the setting-up of specialised institutions for artistic multiculturalism. The latter, exemplified by the International Cultural Centre Caisa, which they examine in detail, provides some interesting reflections on the difficulties faced by different public services to adopt a common discourse, as well as its ability to influence and inform the operations of other public services without a major diversity focus.

An integral approach to the integration of culture in local strategies for sustainable development is presented by the United Cities and Local Government's Agenda 21 for Culture, which provides local authorities with an opportunity to create a long-term vision of culture as a basic pillar of development (Pascual, 2008). On the other hand, the Tallinn Manifesto provides 
public authorities, including in particular local governments, with a framework of areas for action (creative talent, creative business, creative infrastructure, creative cities and regions, creative leadership) on the basis of which to strengthen the creative economy, in a broader framework of sustainable and inclusive development (Fleming et al., 2011).

The need for the involvement of a wide range of actors has been noted by several authors. Sacco et al. stress how for development processes to be successful and sustainable, "[a] variety of agents - the local government, civil society, universities, the educational system, the private sector, and culture producers - must be involved in the developmental process" (2009: 48). A culture council is suggested as one of the instruments to ensure the effective implementation of the Agenda 21 for Culture (Pascual, 2008). Fleming et al. also suggest the setting up of a 'Creative Commission' at local and regional level, as "the major public private partnership for sector development and the core means of ensuring agendas from education to regeneration, economy to arts, are joined up. This should also promote more socially-driven, inclusive and 'bottom-up' approaches to creative development...” (2011: 11).

At an operational level, changes should also take place within local cultural infrastructure, which should increasingly enable creative businesses to collaborate with one another, with the rest of the economy and with less commercial arts initiatives, and which "genuinely brokers and enables the flows between the arts ecology and Creative Economy" (Fleming et al., 2011: 8).

Overall, this collection of literature resources confirms the incipient, but intense, attention being paid to the concepts, arguments and implications of cultural governance, and how the place of culture in contemporary society and as an area of public policy and management is being reconsidered. Interested readers are invited to further explore these issues by consulting the resources listed at the end of this article.

\section{References}

Baumol, W. J. (2003): «Applied Welfare Economics». In Towse, R. (ed.): $A$ Handbook of Cultural Economics, Cheltenham, uK and Northampton, MA: Edward Elgar Publishers, 2003: pp. 20-31. 
Bille Hansen, T. (1997): «The Willingness-to Pay for the Royal Theatre in Copenhagen as a Public Good», Journal of Cultural Economics, 21: pp. 1-28.

Bonet, L. and F. Donato (2011): «The Financial Crisis and its Impact on the Current Models of Governance and Management of the Cultural Sector in Europe», ENCATC Journal of Cultural Management and Policy, 1 (1), pp. 4-11, available at http://www.encatc.org/pages/ fileadmin/user_upload/Journal/JOURNAL_ART_BONET_DONATO_2011.pdf [9 January 2014].

Cos; STichting Kunst and Zaken (2008): Cultural Governance in Nederland: De Stand van Zaken (Cultural governance in the Netherlands: the state of business), available at http://www.culturalgovernance. nl/pages/pdf/Tweemeting\%202009.pdf [01 December 2013]

Cultural Economy Network (2013): Statement of Intent, December 2013.

ČopIČ; V. and A. SRaKar (2012): Cultural Governance: A Literature Review, EENC Paper, January 2012, available at http://www.eenc.info/news/ cultural-governance-literature-review/ [9/1/2014].

Čopič, V.; P. Inkei; A. Kangas and A. Srakar (2013): Trends in Public Funding for Culture in the EU, EENC Report, August 2013.

Fleming, T. and others (2011): The Tallinn Manifesto, manifesto of the International Conference «Creative Entrepreneurship for a Competitive Economy». <http://www.looveesti.ee/attachments/141 Tallinn_Manifesto_Re-thinking the_Creative_Economy_Dec2011. pdf $>$ [9/1/2014].

FöHL, P. S. (2009): «Regionale Kooperationen im Kulturbereich. Begriffe und Systematisierungen». In: FöHL, P.S. and I. NeISEner (eds.): Regionale Kooperationen im Kulturbereich. Theoretische Grundlagen und Praxisbeispiele. Bielefeld: transcript Verlag, pp. 15-45, available at http://www.transcript-verlag.de/ts1050/ts1050_1.pdf $[9$ January 2014].

Foucault, M. (1991): «Governmentality». In Burchell, G.; C. Gordon and P. Miller (eds.): The Foucault Effect: Studies in Governmentality, Chicago, IL: University of Chicago Press, pp. 87-104.

Frey, B. S. and W. W. Pommerehne (1989): Muses and Markets: Explorations in the Economics of the Arts. Basil Blackwell, Oxford.

Holden, J. (2004): Capturing Cultural Value: How Culture Has Become a Tool of Government Policy. London: Demos, available at http://www.demos.co.uk/files/CapturingCulturalValue.pdf [9 January 2014]. 
Holden, J. (2006): Cultural Value and the Crisis of Legitimacy. Why culture needs a democratic mandate. London: Demos, available at http:// www.demos.co.uk/files/Culturalvalueweb.pdf?1240939425 [9 January 2014].

Holden, J. and J. Baltà (2012): The Public Value of Culture: A Literature Review, EENC Paper, January 2012, available at http://www.eenc. info/news/the-public-value-of-culture-literature-review/ [9 January 2014].

KLAIć, D. (2013): Resetting the Stage: Public Theatre between the Market and Democracy, Intellect Ltd.

LindQvist, K. (2012): «Effects of Public Sector Reforms on Management of Cultural Organizations in Europe», International Studies of Management \& Organization, 42 (2): pp.10-29.

Madden, C. (2009): "The Independence of Government Arts Funding: A Review», D'Art Topics in Arts Policy, 9, available at http:// media.ifacca.org/files/Dart9independencereport $\% 281 \% 29 . \mathrm{pdf}$ [9 January 2014].

Matarasso, F. and C. LANDry (1999): Balancing Act: Twenty-one Strategic Dilemmas in Cultural Policy, Cultural Policies Research and Development Unit Policy Note no. 4, Council of Europe Publishing, Strasbourg, available at https://www.leuphana.de/fileadmin/user upload/PERSONALPAGES/Fakultaet_1/Behnke_Christoph/files/ literaturarchiv/Matarasso_Landry.pdf [9 January 2014].

Mercer, C. (2012): From Data to Wisdom: building the knowledge base for cultural policy,11th Annual Experts Assembly of the Council of Europe / ERICarts, Helsinki, June 2012, available at http:// www.culturalpolicies.net/web/files/243/en/Mercer_Helsinki.pdf [03 January 2014].

Pascual, J. (2008): «Cultural Policies, Human Development and Institutional Innovation: Or Why We Need an Agenda 21 for Culture», UNESCO Observatory University of Melbourne Refereed E-journal, 1(2), pp. 9-24, available at http://web.education.unimelb.edu.au/UNESCO/ pdfs/ejournals/jordi-pascual.pdf [9 January 2014].

Perrin. T. (2010): «Inter-Territoriality as a New Trend in Cultural Policy? The Case of Euroregions», Cultural Trends, 19(1): pp. 125-139.

Sacco, P. L; G. Tavano Blessi and M. Nuccio (2009): «Cultural Policies and Local Planning Strategies: What Is the Role of Culture in Local Sustainable Development?», The Journal of Arts Management, Law, and Society, 39(1): pp. 45-64. 
SAukkonen, P. and M. Pyykkönen (2008): «Cultural Policy and Cultural Diversity in Finland», International Journal of Cultural Policy, 14(1): pp. 49-63.

Schmitт, T. (2011): «Cultural Governance as a Conceptual Framework», MMG Working Paper 11-02, Max Planck Institute for the Study of Religious and Ethnic Diversity, available at http://www.geographie. uni-erlangen.de/docs/tschm_publ_work-paper_Cultural-Governance.pdf [03 January 2014].

Seaman, B. A. (1987): «Arts Impact Studies: A Fashionable Excess». In Radich, A. J. (ed.): The Economic Impact of the Arts: A Sourcebook, National Conference of State Legislatures, Denver.

SRAKaR, A. (2010): Ekonomsko vrednotenje umetniških dogodkov: umetnost med trgom in državo, Založba FDv, Ljubljana.

Srakar, A. and V. ČopIČ (2012 a): «Private Investments, Public Values: A Value-Based Approach to Argumenting for Public Support to the Arts», Cultural Trends, Vol. 21, Number 3, September 202, pp. 227-237(11).

Srakar, A. and V. ČopIČ (2012 b): «Public Dimensions of Private Investments in Culture: The "Non-Use Value Argument" Approach», $17^{\text {th }}$ Conference of ACEI, Mimeo.

Stevenson, D.; K. McKaY and D. Rowe (2010): «Tracing British cultural policy domains: contexts, collaborations and constituencies», International Journal of Cultural Policy, 16(2): pp. 159-172.

Throsby, D. (2001): Economics and Culture, Cambridge University Press, Cambridge.

Tотн, A. (2012): «The Economic Performance of the Cultural Sector in the European Union: an Institutional Perspective», 17th Conference of Association for Cultural Economics International, Mimeo, Kyoto 2012.

VvaA (2009): Governance Now: the Hidden Challenge of Leadership, Cultural Leadership Programme, 112 pages, London.

Weber, R. (2010): «What Governance for Culture and the Cultural Sector?», Working document for the Euro-American Campus in Las Palmas de Gran Canaria (November 30th - December 3rd, 2010), http:// www.oei.es/euroamericano/governance Raymond Weber.pdf [03 January 2014].

Zan, L.; S. Bonini Baraldi and C. Gordon (2007): «Cultural Heritage Between Centralisation and Decentralisation: Insights from the Italian Context», International Journal of Cultural Policy, 13(1): pp. 49-70. 